\title{
Predictors of immune reconstitution inflammatory syndrome associated with Kaposi sarcoma (IRIS-KS) in a rural area of Mozambique
}

\author{
E Letang*1, J Almeida², E Ayala1 ${ }^{1}$, JM Miro ${ }^{3}$, C Carrilho ${ }^{4}$, R Bastos ${ }^{5}$, \\ D Nhassone ${ }^{6}, \mathrm{~J} \mathrm{Gascon}^{1}$, C Menendez ${ }^{1}, \mathrm{PL}$ Alonso ${ }^{1}$ and D Naniche ${ }^{1}$
}

\begin{abstract}
Address: ${ }^{1}$ Barcelona Centre for International Health Research, Hospital Clinic-IDIBAPS, University of Barcelona, Barcelona, Spain, ${ }^{2}$ Centro de Investigação em Saude de Manhiça, Manhiça, Mozambique, ${ }^{3}$ Infectious Diseases Service, Hospital Clinic-IDIBAPS, University of Barcelona, Barcelona, Spain, ${ }^{4}$ Department of Pathology, Hospital Central de Maputo, Maputo, Mozambique, ${ }^{5}$ Department of Dermatology, Hospital Central de Maputo, Maputo, Mozambique and ${ }^{6}$ Centro de Saude de Manhiça, Ministerio de Saude de Moçambique, Manhiça, Mozambique

* Corresponding author
\end{abstract}

from Ninth International Congress on Drug Therapy in HIV Infection

Glasgow, UK. 9-13 November 2008

Published: 10 November 2008

Journal of the International AIDS Society 2008, I I (SuppI I):P288 doi:I0.I I86/I758-2652-I I-SI-P288

This abstract is available from: http://www.jiasociety.org/content/I I/SI/P288

(C) 2008 Letang et al; licensee BioMed Central Ltd.

\section{Purpose of the study}

IRIS-KS risk factors are not well known and their identification would aid in selection of the best therapeutic approach for high risk patients. The aim of this study was to identify risk factors for developing IRIS-KS among HIV and Human herpesvirus 8 (HHV-8) co-infected patients receiving cART in Mozambique.

\section{Methods}

This study was integrated into a larger prospective observational study conducted in the Manhiça Health Research Center, designed to characterize IRIS. The cohort described in the present study included those participants in the IRIS cohort with detectable anti-HHV-8 lytic antibodies or with KS at recruitment $(n=69)$. Plasma HIV viral load, CD4 and CD8 counts, immune activation, hepatic and renal function, WBC, RBC and platelet counts, anti-HHV-8 lytic antibodies and plasma and PBMC HHV-8 viral load were assessed at the pre-cART visit and at 4 months after cART initiation. Passive surveillance for potential IRIS-KS cases was performed throughout the study. A univariate and multivariate hazard analysis was carried out in order to assess potential risk factors for developing IRIS-KS among HHV-8 infected patients.

\section{Summary of results}

Thirteen patients presented with KS at the initial pre-cART visit and four additional patients were diagnosed with KS after cART initiation. Eight patients out of 69 (11.6\%) experienced either an abrupt clinical worsening (four) or debuted with KS (four) with a median time of 13.8 weeks (IQR, 3-23) after cART initiation, in the context of a mean $2.58 \log 10$ copies/mL (sd 0.2) decline in plasma HIVRNA viral load and a median increase of $95 \mathrm{CD} 4+$ cells/ $\mu \mathrm{l}$ (IQR, 6-136) from pre-cART levels. Multivariate hazard analysis showed that, at pre-cART visit, a plasma HIV-RNA viral $\operatorname{load}>5 \log 10$ copies $/ \mathrm{mL}$, a body mass index $(\mathrm{BMI})<18.5$ and the presence of KS were independently associated with the development of IRIS-KS. At 4 months after CART, IRIS-KS cases tended to have achieved a better HIV virologic control and a higher absolute change in anti-HHV-8 lytic antibodies than those HHV-8 infected patients that did not develop IRIS-KS. In order to better characterize the relation between HHV-8 and IRIS-KS, determination of HHV-8 DNA loads is currently underway.

\section{Conclusion}

In this cohort of antiretroviral-naïve HIV and HHV-8 coinfected African patients, IRIS-KS was observed in $11.6 \%$ of patients. A plasma HIV-1 RNA viral load $>5 \log 10$ cop- 
ies/mL, a $\mathrm{BMI}<18.5$, and the presence of $\mathrm{KS}$ at baseline were independent predictors of IRIS-KS. Close clinical supervision is warranted for these patients.

\section{References}

I. Leidner RS, Aboulafia DM: Recrudescent Kaposi's sarcoma after initiation of HAART: a manifestation of immune reconstitution syndrome. AIDS Patient Care STDS 2005, 1 9(10):635-44.

2. El Amari EB, et al.: Predicting the evolution of Kaposi sarcoma, in the highly active antiretroviral therapy era. AIDS 2008 , 22(9):1019-28.

Publish with Bio Med Central and every scientist can read your work free of charge

"BioMed Central will be the most significant development for disseminating the results of biomedical research in our lifetime. " Sir Paul Nurse, Cancer Research UK

Your research papers will be:

- available free of charge to the entire biomedical community

- peer reviewed and published immediately upon acceptance

- cited in PubMed and archived on PubMed Central

- yours - you keep the copyright

Submit your manuscript here:

http://www.biomedcentral.com/info/publishing_adv.asp 